\title{
Pengolahan Air Limbah Domestik Menggunakan Proses Aerasi, Pengendapan, dan Filtrasi Media Zeolit-Arang Aktif
}

\author{
Afiya Asadiya dan Nieke Karnaningroem \\ Departemen Teknik Lingkungan, Fakultas Teknik Sipil, Lingkungan, dan Kebumian, Institut \\ Teknologi Sepuluh Nopember (ITS) \\ e-mail: nieke@enviro.its.ac.id
}

\begin{abstract}
Abstrak - Produksi air limbah domestik khususnya greywater yang dihasilkan dari aktivitas manusia setiap harinya semakin meningkat sejalan dengan peningkatan jumlah penduduk. Adapun kualitas air limbah domestik masih jauh melebihi baku mutu yang telah ditetapkan pemerintah. Air limbah domestik atau rumah tangga yang tidak diolah secara benar dapat menyebabkan berbagai macam masalah bagi manusia dan lingkungan sekitarnya. Diperlukan pengolahan yang tepat untuk dapat mengolah air limbah domestik agar dapat memenuhi baku mutu air bersih, dan dapat digunakan sebagai sumber air bersih oleh masyarakat. Penelitian ini dilakukan untuk menentukan efektivitas pengolahan air limbah dengan menggunakan proses aerasi, sedimentasi dan filtrasi media zeolit-arang aktif menggunakan sistem kontinyu. Proses aerasi dilakukan dengan penambahan larutan EM4 sebagai pengolah zat organik yang ada pada air limbah, dan kemudian air limbah akan melewati bak pengendap untuk mengendapkan zat padat yang terkandung didalamnya. Selanjutnya, air limbah akan diolah menggunakan filter dengan media zeolit dan arang aktif. Setelah melewati serangkaian pengolahan dengan proses aerasi, sedimentasi, dan filtrasi menggunakan zeolit dan arang aktif, hasil penelitian menunjukkan terjadinya penurunan kandungan pencemar pada air limbah. Rata-rata penyisihan kandungan zat organik adalah ialah $93,14 \%$, rata-rata penyisihan nilai $N$ adalah $99,81 \%$, ratarata penyisihan nilai $P$ adalah $99,67 \%$, dan rata-rata penyisihan nilai TDS mencapai $84,76 \%$, serta nilai penyisihan TSS ialah 99,97\%.
\end{abstract}

Kata Kunci- Air Limbah, Arang Aktif, EM4, Filtrasi, Zeolit.

\section{PENDAHULUAN}

A ir limbah domestik telah menjadi isu penting yang timbul sejalan dengan terus meningkatnya populasi manusia dan kemajuan pembangunan yang semakin pesat. Kementerian Lingkungan Hidup Indonesia pada tahun 2014 mengeluarkan hasil studi bahwa 60-70 \% sungai di Indonesia telah tercemar limbah domestik atau rumah tangga. Air limbah domestik atau rumah tangga yang tidak diolah secara benar dapat menyebabkan berbagai macam masalah bagi manusia dan lingkungan sekitarnya. Pada umumnya, karakteristik dari air limbah domestik diantaranya adalah TSS 25-183 mg/l, COD 100-700 mg/l, BOD 47-466 mg/l, Total Coliform 56-8,03×107 CFU/100 ml [1]. Air Limbah domestik yang merupakan air buangan rumah tangga yang dibuang ke badan air dapat berpotensi menjadi salah satu sumber air baku untuk air bersih. Pengolahan ulang air limbah domestik dimaksudkan supaya air limbah domestik dapat dimanfaatkan menjadi air bersih dan memenuhi baku mutu air bersih.
Berdasarkan pada uraian diatas, perlu adanya metode yang efisien dan tepat guna untuk pengolahan air limbah domestik. Penelitian ini mengambil lokasi studi kasus di kawasan Perumahan Bhaskara Jaya, Mulyosari, Surabaya. Lokasi ini dipilih karena berdasarkan penelitian awal karakteristik air limbah domestik Perumahan Bhaskara Jaya yang dilakukan di Laboratorium Kualitas Lingkungan Jurusan Tekinik Lingkungan, kadungan pencemar dalam air limbah Perumahan Bhaskara Jaya cukup tinggi, yakni nilai COD yang bernilai 160 $\mathrm{mg} / \mathrm{L}$ dengan baku mutu yang diizinkan untuk limbah domestik adalah $30 \mathrm{mg} / \mathrm{L}$. Selain itu, kadar nitrat yang tinggi, yakni bernilai 26,65 mg/L dari baku mutu $10 \mathrm{mg} / \mathrm{L}$, dan nilai TSS yakni $150 \mathrm{mg} / \mathrm{L}$ dari baku mutu yang diizinkan $30 \mathrm{mg} / \mathrm{L}$.

Pengolahan yang digunakan adalah proses aerasi dengan penambahan bakteri EM4 sebagai proses secara biologi dan dilanjutkan dengan proses pengendapan dan filtrasi yang menggunakan media arang aktif. Aerasi adalah proses dilakukannya kontak antara air dan udara baik dengan cara natural maupun dengan desain mekanis untuk meningkatkan kadar oksigen terlarut dalam air [2]. Penurunan kadar BOD dengan proses aerasi mencapai 50 persen, sedangkan untuk kadar COD penurunan dapat mencapai 62 persen [3]. Proses aerasi yang merupakan proses pengolahan secara biologis dengan adanya penambahan EM 4, menjadi proses sangat penting karena pada pengolahan air limbah domestik memanfaatkan bakteri aerob untuk mereduksi zat organik dalam air limbah domestik, khususnya BOD dan COD. Berdasarkan penelitian terdahulu, dengan menggunakan EM4, penurunan kadar BOD dan COD dalam air limbah dapat mencapai 93\% [4].

Pengolahan yang digunakan adalah dengan aerasi, filtrasi dan pengendapan. Pengendapan dilakukan agar flok yang terbentuk dari proses aerasi dapat tersendapkan. Pengolahan selanjutnya adalah proses filtrasi yang menggunakan media zeolit dan arang aktif. Perpaduan aerasi, pengendapan, dan filtrasi dengan menggunakan media zeolit dan arang aktif digunakan untuk memperoleh tingkat efisiensi removal yang tinggi untuk setiap parameter pada air limbah domestik. Berdasarkan penelitian terdahulu yang telah dilakukan, penurunan kadar COD dengan pengolahan menggunakan proses aerasi dan filtrasi mecapai 81,7\% [5].

\section{METODE PENELITIAN}

\section{A. Lokasi Sampling}

Lokasi sampling untuk penelitian kali ini berada di Perumahan Komplek Bhaskara Jaya Mulyosari, Kecamatan 
Mulyorejo Kota Surabaya. Wilayah ini berada pada koordinat 7016'05.71'’ LU, dan 11247'57.46'” LS. Titik sampling untuk karakteristik awal air limbah domestik yang ada pada perumahan ini diambil pada saluran air (selokan) di depan rumah warga, untuk nantinya dibandingkan dengan Baku Mutu Air Limbah Domestik (Permen LH No. 68 Tahun 2016). Sedangkan lokasi titik sampling untuk air baku proses pengolahan diambil di muara saluran pengumpul akhir air limbah domestik sebelum dibuang ke badan air.

\section{B. Variabel Penelitian}

1. Variabel Media Filter

Media yang akan digunakan pada penelitian kali ini adalah arang aktif serta zeolit yang tidak diaktivasi. Terdapat 3 reaktor filter yang digunakan, dengan komposisi media filter yang berbeda, dengan tinggi total media adalah $70 \mathrm{~cm}$. Adapun variasi media filter adalah sebagai berikut:
a. Media zeolit : arang aktif $=75 \%: 25 \%$
b. Media zeolit : arang aktif $=50 \%: 50 \%$
c. Media zeolit : arang aktif $=25 \%: 75 \%$

2. Variabel Dosis Penambahan EM4

Dosis EM4 yang optimum untuk penyisihan zat organik dan TSS pada air limbah yaitu dengan penambahan EM4 sebanyak 5\% dari total debit air yang akan diolah [6]. Volume air yang akan diolah pada penelitian kali ini adalah $10 \mathrm{~L}$, sehingga pada penelitian kali ini variasi dosis penambahan EM4 adalah:

a. Tanpa penambahan EM4

b. $5 \%$ dari total debit olahan, yakni $0,5 \mathrm{~L} / \mathrm{jam}$

c. $10 \%$ dari total debit olahan, yakni $1 \mathrm{~L} / \mathrm{jam}$ Tabel 1.

Variabel Penelitian

\begin{tabular}{ll}
\multicolumn{2}{c}{ Variabel Penelitian } \\
\hline \hline Variabel & \\
\hline A1 & Media Zeolith:Arang Aktif $=75 \%: 25 \%$ \\
A2 & Media Zeolith:Arang Aktif $=50 \%: 50 \%$ \\
A3 & Media Zeolith:Arang Aktif $=25 \%: 75 \%$ \\
C1 & Dosis penambahan EM4 terhadap debit 0\% \\
C2 & Dosis penambahan EM4 terhadap debit 5\% \\
C3 & Dosis penambahan EM4 terhadap debit 10\% \\
\hline \hline
\end{tabular}

\section{Parameter}

Parameter yang digunakan pada penelitian kali ini adalah kadar $\mathrm{BOD}_{5}, \mathrm{COD}, \mathrm{N}, \mathrm{P}$ dan TSS untuk uji karakteristik awal kandungan air limbah. Parameter-parameter ini dibandingkan dengan Baku Mutu Air Limbah Domestik (Permen LH No. 68 Tahun 2016). Sedangkan, untuk air hasil pengolahan, parameter yang digunakan adalah kandungan kadar zat organik, nilai nitrat, phosphat, Total Dissolved Solid (TDS), dan Total Suspended Solid (TSS). Air hasil olahan akan dibandingkan dengan Baku Mutu Air Bersih (Permenkes No. 32 Tahun 2017).

\section{Reaktor}

Penelitian akan mengolah air limbah domestik dengan menggunakan reaktor yang disusun secara paralel, dimana terdapat bak aerasi dengan penambahan EM4 dan bak pengendap untuk mengendapkan padatan terlarut dan tersuspensi, serta terdapat tiga buah reaktor filter yang berisi kombinasi media zeolit dan arang aktif dengan ketinggian total $70 \mathrm{~cm}$ [7].

Reaktor yang digunakan adalah rangkaian dari unit aerasi, sedimentasi, dan filtrasi. Reaktor dibuat dengan skala laboratorium. Persiapan reaktor adalah sebagai berikut:

\section{Reaktor Kaca}

Reaktor kaca digunakan sebagai reaktor filter. Ukuran yang digunakan yakni $9 \mathrm{~cm}$ x $9 \mathrm{~cm} \times 100 \mathrm{~cm}$, dengan ketebalan kaca $0,5 \mathrm{~cm}$.

\section{Bak penampung air baku}

Bak penampung digunakan sebgai wadah air sampel sebelum dipompa dan dimasukkan ke dalam unit pengolahan pertama, yakni bak aerasi.

\section{Bak Aerasi}

Bak aerasi digunakan untuk aerasi dengan penambahan EM4.

4. Bak Pengendap

Bak pengendap berukuran $63 \mathrm{~cm} \times 18 \mathrm{~cm} \times 10 \mathrm{~cm}$. Dilengkapi dengan gutter sebagai outletnya.

5. Selang dan Keran Air

Selang air digunakan untuk mengalirkan air dari unit ke unit. Selang digunakan karena karakteristiknya yang lentur dan mudah dibentuk. Kran air plastik akan digunakan sebagai valve untuk mengatur debit dan mengambil contoh air yang telah diolah oleh filter dengan media arang aktif dan zeolit.

6. Bak Penampung Effluen Hasil Pengolahan

Bak penampung digunakan sebagai wadah air sampel setelah melewati filter. Ketinggian bak penampung effluen tidak melebihi ketinggian dari dasar media filter.

Sketsa denah dan tampak samping reaktor yang akan digunakan pada penelitian ini dapat dilihat pada Gambar 1.

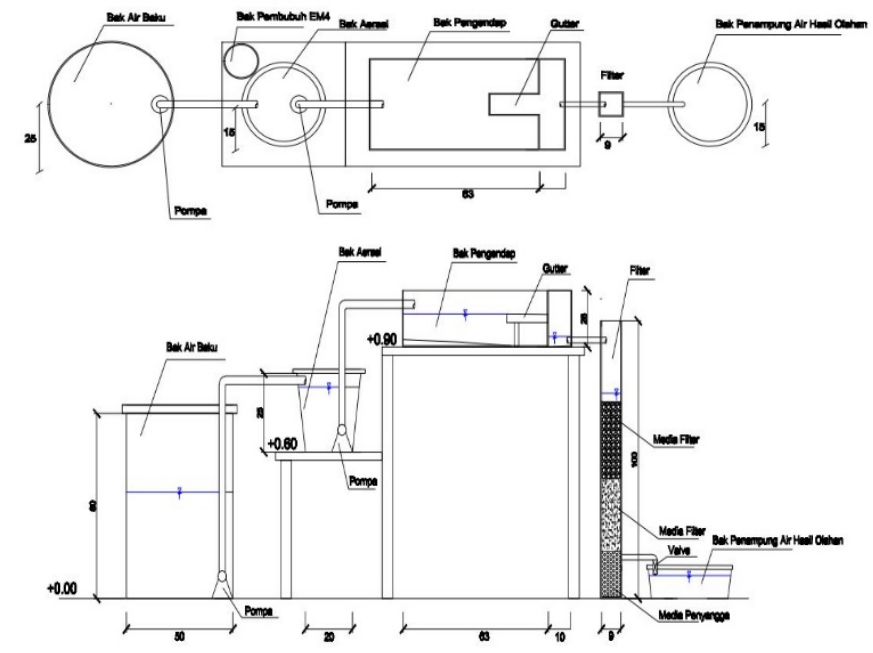

Gambar 1. Reaktor Penelitian

\section{HASIL DAN PEMBAHASAN}

\section{A. Analisis Karakteristik Awal Air Limbah}

Penelitian ini diawali dengan penelitian karakteristik awal air limbah untuk mengetahui karakteristik awal air limbah domestik yang akan diolah. Hasil dari penelitian pendahuluan ini akan dijadikan sebagai acuan kemampuan pengolahan dalam menyisihkan beban pencemar. Penelitian awal ini menguji delapan parameter pencemar pada air limbah berdasarkan Peraturan Menteri Lingkungan Hidup No. 68 Tahun 2016 tentang Baku Mutu Air Limbah Domestik. Hasil yang diperoleh dari penelitian awal karakteristik air limbah 
dapat dilihat pada Tabel 2.

Tabel 2.

Hasil Pengujian Karakteristik Awal Air Limbah Domestik Perumahan Bhaskara Jaya

\begin{tabular}{lllcl}
\hline \hline No. & Parameter & Satuan & $\begin{array}{c}\text { Baku } \\
\text { Mutu Air } \\
\text { Limbah } \\
\text { Domestik* }\end{array}$ & $\begin{array}{c}\text { Hasil } \\
\text { Analisis }\end{array}$ \\
\hline 1 & $\mathrm{pH}$ & - & $6-9$ & 6,85 \\
2 & $\mathrm{TSS}$ & $\mathrm{mg} / \mathrm{L}$ & 30 & 150,00 \\
3 & $\mathrm{TDS}$ & $\mathrm{mg} / \mathrm{L}$ & $(-)$ & 89,1 \\
4 & $\mathrm{COD}$ & $\mathrm{mg} / \mathrm{L} \mathrm{O}_{2}$ & 100 & 160,00 \\
5 & BOD & $\mathrm{mg} / \mathrm{L} \mathrm{O}_{2}$ & 30 & 81,90 \\
6 & DO & $\mathrm{mg} / \mathrm{L} \mathrm{O}_{2}$ & $(-)$ & 0,00 \\
7 & Nitrat & $\mathrm{mg} / \mathrm{L} \mathrm{NO}_{3}-\mathrm{N}$ & 10 & 26,55 \\
8 & Pospat & $\mathrm{mg} / \mathrm{L} \mathrm{PO}_{4}-\mathrm{P}$ & $(-)$ & 13,89 \\
\hline
\end{tabular}

*). Mengacu pada Peraturan Menteri Lingkungan Hidup No. 68 Tahun 2016

Baku mutu yang digunakan untuk air hasil olahan dalam penelitian ini mengacu pada baku mutu air bersih, yaitu Peraturan Menteri Kesehatan No. 32 Tahun 2017 tentang Standar Baku Mutu Kesehatan Lingkungan dan Persyaratan Kesehatan Air untuk Keperluan Higiene Sanitasi, Kolam Renang, Solus Per Aqua, dan Pemandian Umum. Berdasarkan hasil penelitian awal karakteristik air limbah yang terlihat pada Tabel 4.1, air baku limbah domestik yang akan diolah memiliki nilai diatas baku mutu pada setiap parameter, sehingga diperlukan pengolahan lebih lanjut untuk memenuhi baku mutu air bersih.

\section{B. Parameter Nilai Kandungan Zat Organik}

Tabel 3. berisi nilai kandungan dan presentase penyisihan parameter kandungan zat organik setelah melewati serangkaian proses pengolahan, yakni aerasi, sedimentasi dan pengendapan. Pada proses filtrasi, hasil yang tertera pada $\backslash$ adalah hasil filtrasi pada menit ke-120, dimana menit ke-120 merupakan waktu pengolahan yang optimum untuk filter pada penelitian ini.

Tabel 3.

Presentase Penyisihan Parameter Kandungan Zat Organik

\begin{tabular}{|c|c|c|c|c|}
\hline \multirow{3}{*}{ Proses } & \multirow{3}{*}{$\begin{array}{c}\text { Dosis } \\
\text { Penam } \\
\text { bahan } \\
\text { EM4 }\end{array}$} & \multirow{9}{*}{$\begin{array}{c}\text { Komposisi } \\
\text { Media } \\
\text { Filter; } \\
\text { Zeolit:Arang } \\
\text { Aktif }\end{array}$} & \multicolumn{2}{|c|}{$\begin{array}{l}\text { Hasil Pengolahan Aerasi, } \\
\text { Sedimentasi, dan Filtrasi }\end{array}$} \\
\hline & & & $\begin{array}{c}\text { Nilai Zat } \\
\text { Organik } \\
\text { Setelah } \\
\text { Proses } \\
(\mathrm{mg} / \mathrm{L}) \\
\end{array}$ & $\begin{array}{c}\% \\
\text { Penyisihan } \\
\text { Zat Organik }\end{array}$ \\
\hline & & & \multicolumn{2}{|c|}{ Konsentrasi Awal: 50 mg/L } \\
\hline \multirow{3}{*}{ Aerasi } & $0 \%$ & & 18,67 & 62,67 \\
\hline & $5 \%$ & & 17,33 & 65,33 \\
\hline & $10 \%$ & & 13,33 & 73,33 \\
\hline \multirow{3}{*}{$\begin{array}{c}\text { Sedi- } \\
\text { men- } \\
\text { tasi }\end{array}$} & $0 \%$ & & 16,00 & 68,00 \\
\hline & $5 \%$ & & 16,00 & 68,00 \\
\hline & $10 \%$ & & 16,00 & 68,00 \\
\hline \multirow{9}{*}{$\begin{array}{l}\text { Filtrasi } \\
\text { pada } \\
\text { menit } \\
\text { ke-120 }\end{array}$} & & $25: 75$ & 2,4 & 85,00 \\
\hline & $0 \%$ & $50: 50$ & 4,2 & 73,75 \\
\hline & & $75: 25$ & 2,4 & 85,00 \\
\hline & & $25: 75$ & 2,4 & 85,00 \\
\hline & $5 \%$ & $50: 50$ & 1,8 & 88,75 \\
\hline & & $75: 25$ & 4,2 & 73,75 \\
\hline & & $25: 75$ & 2,4 & 85,00 \\
\hline & $10 \%$ & $50: 50$ & 4,2 & 73,75 \\
\hline & & $75: 25$ & 4,8 & 70,00 \\
\hline
\end{tabular}

Mengacu pada Peraturan Menteri Kesehatan RI No. 32 Tahun 2017 tentang Baku Mutu Air Bersih yang diperuntukan untuk Higiene dan Sanitasi, nilai kandungan zat organik yang diizinkan pada air limbah domestik adalah $10 \mathrm{mg} / \mathrm{L}$. Melalui pengolahan ini, effluen air hasil pengolahan pada variabel C2A2, pada menit ke-120 penyisihan nilai zat organik mencapai 93,14\% dengan nilai zat organik adalah $1,8 \mathrm{mg} / \mathrm{L}$, sehingga sudah memenuhi baku mutu air bersih.

\section{Parameter Nilai Total Dissolved Solid (TDS)}

Kandungan Total Dissolved Solid (TDS) air limbah pada penelitian ini menunjukkan kandungan padatan terlarut yang ada pada air limbah. Berdasarkan penelitian yang telah dilakukan, hasil analisis kandungan TDS pada air yang telah melewati pengolahan dapat dilihat pada Tabel 4. Tabel 4 . menampilkan nilai akhir TDS dan persen penyisihan dari setiap tahapan pengolahan, dimana nilai awal kandungan TDS pada air sebelum diolah adalah $161 \mathrm{mg} / \mathrm{L}$.

Tabel 4.

Presentase Penyisihan Parameter Nilai Total Dissolved Solid (TDS)

\begin{tabular}{|c|c|c|c|c|}
\hline \multirow{3}{*}{ Proses } & \multirow{3}{*}{$\begin{array}{c}\text { Dosis } \\
\text { Penam } \\
\text { bahan } \\
\text { EM4 }\end{array}$} & \multirow{3}{*}{$\begin{array}{c}\text { Komposisi } \\
\text { Media } \\
\text { Filter; } \\
\text { Zeolit:Arang } \\
\text { Aktif }\end{array}$} & \multicolumn{2}{|c|}{$\begin{array}{c}\text { Hasil Pengolahan } \\
\text { Aerasi, Sedimentasi, } \\
\text { dan Filtrasi }\end{array}$} \\
\hline & & & $\begin{array}{c}\text { Nilai } \\
\text { TDS } \\
\text { Setelah } \\
\text { Proses } \\
\text { (mg/L) }\end{array}$ & $\begin{array}{c}\% \\
\text { Penyisihan } \\
\text { TDS }\end{array}$ \\
\hline & & & \multicolumn{2}{|c|}{$\begin{array}{c}\text { Konsentrasi Awal: } 161 \\
\text { mg/L }\end{array}$} \\
\hline \multirow{3}{*}{ Aerasi } & $0 \%$ & & 140 & 13,04 \\
\hline & $5 \%$ & & 130 & 19,25 \\
\hline & $10 \%$ & & 100 & 37,89 \\
\hline \multirow{3}{*}{$\begin{array}{l}\text { Sedi- } \\
\text { men- } \\
\text { tasi }\end{array}$} & $0 \%$ & & 120 & 25,47 \\
\hline & $5 \%$ & & 120 & 25,47 \\
\hline & $10 \%$ & & 120 & 25,47 \\
\hline \multirow{9}{*}{$\begin{array}{c}\text { Filtrasi } \\
\text { pada } \\
\text { menit } \\
\text { ke-120 }\end{array}$} & & $25: 75$ & 16 & 86,67 \\
\hline & $0 \%$ & $50: 50$ & 28 & 76,67 \\
\hline & & $75: 25$ & 16 & 86,67 \\
\hline & & $25: 75$ & 16 & 86,67 \\
\hline & $5 \%$ & $50: 50$ & 12 & 90,00 \\
\hline & & $75: 25$ & 28 & 76,67 \\
\hline & & $25: 75$ & 16 & 86,67 \\
\hline & $10 \%$ & $50: 50$ & 28 & 76,67 \\
\hline & & $75: 25$ & 32 & 73,33 \\
\hline
\end{tabular}

Mengacu pada Peraturan Menteri Kesehatan RI No. 32 Tahun 2017 tentang Baku Mutu Air Bersih (Air Higiene Sanitasi), nilai kandungan TDS maksimum yang diizinkan pada air bersih adalah $1000 \mathrm{mg} / \mathrm{L}$. Melalui pengolahan ini, effluen air hasil pengolahan pada variabel C2-A2, nilai TDS adalah 12 $\mathrm{mg} / \mathrm{L}$ pada menit ke-120, sehingga sudah memenuhi baku mutu air bersih yang dipergunakan sebagai air higiene sanitasi.

\section{Parameter Nilai Fosfat}

Kandungan fosfat air limbah pada penelitian ini dilihat dari nilai $\mathrm{PO}_{4}$ - yang merupakan nutrien terlarut dalam air limbah, yang sebagian besar berasal dari kandungan deterjen pada air limbah. Berdasarkan penelitian yang telah dilakukan, hasil analisis kandungan fosfat pada air yang telah melewati pengolahan dapat dilihat pada Tabel 5. Tabel 5 menampilkan nilai akhir fosfat dan persen penyisihan dari setiap tahapan pengolahan, dimana nilai awal kandungan fosfat pada air sebelum diolah adalah 13,89 mg/L. 
Tabel 5.

Presentase Penyisihan Parameter Nilai Fosfat

\begin{tabular}{|c|c|c|c|c|}
\hline \multirow{3}{*}{ Proses } & \multirow{3}{*}{$\begin{array}{c}\text { Dosis } \\
\text { Penam } \\
\text { bahan } \\
\text { EM4 }\end{array}$} & \multirow{9}{*}{$\begin{array}{l}\text { Komposisi } \\
\text { Media } \\
\text { Filter; } \\
\text { Zeolit:Aran } \\
\text { g Aktif }\end{array}$} & \multicolumn{2}{|c|}{$\begin{array}{c}\text { Hasil Pengolahan Aerasi, } \\
\text { Sedimentasi, dan Filtrasi }\end{array}$} \\
\hline & & & $\begin{array}{c}\text { Nilai P } \\
\text { Setelah } \\
\text { Proses } \\
(\mathrm{mg} / \mathrm{L})\end{array}$ & $\begin{array}{c}\% \\
\text { Penyisihan P }\end{array}$ \\
\hline & & & \multicolumn{2}{|c|}{ Konsentrasi Awal: 13,89 mg/L } \\
\hline \multirow{3}{*}{ Aerasi } & $0 \%$ & & 5,12 & 63,14 \\
\hline & $5 \%$ & & 3,03 & 78,17 \\
\hline & $10 \%$ & & 4,94 & 64,45 \\
\hline \multirow{3}{*}{$\begin{array}{c}\text { Sedi- } \\
\text { men- } \\
\text { tasi }\end{array}$} & $0 \%$ & & 3,94 & 71,61 \\
\hline & $5 \%$ & & 4,09 & 70,53 \\
\hline & $10 \%$ & & 2,98 & 78,53 \\
\hline \multirow{9}{*}{$\begin{array}{l}\text { Filtrasi } \\
\text { pada } \\
\text { menit } \\
\text { ke-120 }\end{array}$} & \multirow{3}{*}{$0 \%$} & $25: 75$ & 0,05 & 98,85 \\
\hline & & $50: 50$ & 0,05 & 98,85 \\
\hline & & $75: 25$ & 0,05 & 98,83 \\
\hline & \multirow{3}{*}{$5 \%$} & $25: 75$ & 0,05 & 98,88 \\
\hline & & $50: 50$ & 0,05 & 98,85 \\
\hline & & $75: 25$ & 0,04 & 98,93 \\
\hline & \multirow{3}{*}{$10 \%$} & $25: 75$ & 0,05 & 98,45 \\
\hline & & $50: 50$ & 0,05 & 98,49 \\
\hline & & $75: 25$ & 0,05 & 98,49 \\
\hline
\end{tabular}

Mengacu pada Peraturan Menteri Kesehatan RI No. 32 Tahun 2017 tentang Baku Mutu Air Bersih yang diperuntukan untuk Higiene dan Sanitasi, nilai fosfat dalam air limbah tidak boleh melebihi $0,05 \mathrm{mg} / \mathrm{L}$. Melalui pengolahan ini, effluen air hasil pengolahan pada variabel C2-A2, nilai P adalah $0,05 \mathrm{mg} / \mathrm{L}$ pada menit ke-120, sehingga sudah memenuhi baku mutu air bersih yang dipergunakan sebagai air higiene sanitasi.

\section{E. Parameter Nilai Nitrat}

Kandungan nitrat air limbah pada penelitian ini dilihat dari nilai ammonia $\mathrm{NO}_{3}^{-}-\mathrm{N}$ yang merupakan nutrien terlarut dalam air limbah. Berdasarkan penelitian yang telah dilakukan, hasil analisis kandungan nitrat pada air yang telah melewati pengolahan dapat dilihat pada Tabel 6. Tabel 6 menampilkan nilai akhir nitrat dan persen penyisihan dari setiap tahapan pengolahan, dimana nilai awal kandungan nitrat pada air sebelum diolah adalah 26,55 mg/L.

Tabel 6.

Presentase Penyisihan Parameter Nilai Nitrat

\begin{tabular}{|c|c|c|c|c|}
\hline \multirow{3}{*}{ Proses } & \multirow{3}{*}{$\begin{array}{c}\text { Dosis } \\
\text { Penam } \\
\text { bahan } \\
\text { EM4 }\end{array}$} & \multirow{3}{*}{$\begin{array}{l}\text { Komposis } \\
\text { i Media } \\
\text { Filter; } \\
\text { Zeolit:Ar } \\
\text { ang Aktif }\end{array}$} & \multicolumn{2}{|c|}{$\begin{array}{c}\text { Hasil Pengolahan } \\
\text { Aerasi, Sedimentasi, } \\
\text { dan Filtrasi }\end{array}$} \\
\hline & & & $\begin{array}{l}\text { Nilai N } \\
\text { Setelah } \\
\text { Proses } \\
\text { (mg/L) }\end{array}$ & $\begin{array}{c}\% \\
\text { Penyisihan } \\
\text { N }\end{array}$ \\
\hline & & & \multicolumn{2}{|c|}{$\begin{array}{c}\text { Konsentrasi Awal: 26,55 } \\
\text { mg/L }\end{array}$} \\
\hline \multirow{3}{*}{ Aerasi } & $0 \%$ & & 0,20 & 99,26 \\
\hline & $5 \%$ & & 0,15 & 99,42 \\
\hline & $10 \%$ & & 0,01 & 99,95 \\
\hline \multirow{3}{*}{$\begin{array}{c}\text { Sedi- } \\
\text { men- } \\
\text { tasi }\end{array}$} & $0 \%$ & & 0,14 & 99,47 \\
\hline & $5 \%$ & & 0,10 & 99,63 \\
\hline & $10 \%$ & & 0,40 & 98,51 \\
\hline \multirow{3}{*}{$\begin{array}{l}\text { Filtrasi } \\
\text { pada } \\
\text { menit } \\
\text { ke-120 }\end{array}$} & & $25: 75$ & 0,47 & $-233,25$ \\
\hline & $0 \%$ & $50: 50$ & 4,56 & $-3153,93$ \\
\hline & & $75: 25$ & 0,01 & 91,27 \\
\hline
\end{tabular}

\begin{tabular}{cccc}
$5 \%$ & $25: 75$ & 0,13 & $-29,15$ \\
& $50: 50$ & $\mathbf{0 , 0 1}$ & 87,45 \\
& $75: 25$ & 0,14 & $-43,73$ \\
\hline \multirow{2}{*}{$10 \%$} & $25: 75$ & 13,54 & $-3320,09$ \\
& $50: 50$ & 0,01 & 96,91 \\
& $75: 25$ & 0,10 & 75,37 \\
\hline
\end{tabular}

Pada nilai kandungan nitrat, terdapat presentase penyisihan yang bernilai negatif, dimana hal ini disebabkan karena tidak dilakukan pencucian pada media filter, sehingga terdapat kandungan pengotor pada filter dan menyebabkan naiknya kandungan zat pencemar yaitu nitrat.

Jika mengacu pada Peraturan Menteri Kesehatan RI No. 32 Tahun 2017 tentang Baku Mutu Air Bersih yang diperuntukan untuk Higiene dan Sanitasi, nilai kandungan $\mathrm{N}$ yang diizinkan pada air limbah domestik adalah $10 \mathrm{mg} / \mathrm{L}$. Melalui pengolahan ini, effluen air hasil pengolahan pada variabel C2-A2 pada menit ke-120 penyisihan nilai N mencapai 99,95\% dengan nilai $\mathrm{N}$ adalah $0,05 \mathrm{mg} / \mathrm{L}$, sehingga sudah memenuhi baku mutu air bersih.

\section{F. Parameter Nilai Total Suspended Solid (TSS)}

Kandungan Total Suspended Solid (TSS) air limbah pada penelitian ini menunjukkan kandungan padatan terlarut yang ada pada air limbah. Parameter ini adalah parameter tambahan untuk melihat endapan yang ada pada air hasil olahan. Berdasarkan penelitian yang telah dilakukan, hasil analisis kandungan TSS pada air yang telah melewati pengolahan dapat dilihat pada Tabel 7. Tabel 7 menampilkan nilai akhir TSS dan persen penyisihan dari setiap tahapan pengolahan, dimana nilai awal kandungan TSS pada air sebelum diolah adalah $150 \mathrm{mg} / \mathrm{L}$.

Tabel 7.

Presentase Penyisihan Parameter Nilai TSS

\begin{tabular}{|c|c|c|c|c|}
\hline \multirow{3}{*}{ Proses } & \multirow{3}{*}{$\begin{array}{c}\text { Dosis } \\
\text { Penam } \\
\text { bahan } \\
\text { EM4 }\end{array}$} & \multirow{3}{*}{$\begin{array}{c}\text { Komposi } \\
\text { si Media } \\
\text { Filter; } \\
\text { Zeolit:A } \\
\text { rang } \\
\text { Aktif }\end{array}$} & \multicolumn{2}{|c|}{$\begin{array}{c}\text { Hasil Pengolahan } \\
\text { Aerasi, Sedimentasi, } \\
\text { dan Filtrasi }\end{array}$} \\
\hline & & & $\begin{array}{l}\text { Nilai TSS } \\
\text { Setelah } \\
\text { Proses } \\
\text { (mg/L) }\end{array}$ & $\begin{array}{c}\% \\
\text { Penyisih } \\
\text { an TSS }\end{array}$ \\
\hline & & & \multicolumn{2}{|c|}{$\begin{array}{c}\text { Konsentrasi Awal: } 150 \\
\text { mg/L }\end{array}$} \\
\hline \multirow{3}{*}{ Aerasi } & $0 \%$ & & 2,78 & 98,14 \\
\hline & $5 \%$ & & 0,04 & 99,98 \\
\hline & $10 \%$ & & 0,04 & 99,98 \\
\hline \multirow{3}{*}{$\begin{array}{l}\text { Sedi-men- } \\
\quad \text { tasi }\end{array}$} & $0 \%$ & & 0,12 & 99,92 \\
\hline & $5 \%$ & & 0,15 & 99,90 \\
\hline & $10 \%$ & & 0,14 & 99,91 \\
\hline \multirow{6}{*}{$\begin{array}{l}\text { Filtrasi } \\
\text { pada } \\
\text { menit ke- } \\
120\end{array}$} & \multirow{3}{*}{$0 \%$} & $25: 75$ & 0,44 & $-254,84$ \\
\hline & & $50: 50$ & 0,02 & 80,65 \\
\hline & & $75: 25$ & 0,09 & 29,03 \\
\hline & \multirow{3}{*}{$5 \%$} & $25: 75$ & 0,12 & 16,22 \\
\hline & & $50: 50$ & 0,04 & 72,97 \\
\hline & & $75: 25$ & 0,10 & 32,43 \\
\hline
\end{tabular}




\begin{tabular}{cccc}
\hline & $25: 75$ & 0,08 & 44,12 \\
$10 \%$ & $50: 50$ & 12,79 & $-9305,88$ \\
& $75: 25$ & 0,50 & $-264,71$ \\
\hline \hline
\end{tabular}

Jika mengacu pada Peraturan Menteri Kesehatan RI No. 32 Tahun 2017 tentang Baku Mutu Air Bersih yang diperuntukan untuk Higiene dan Sanitasi Pada penelitian ini, nilai TSS sebagai parameter tambahan yang mengindikasikan bahwa air limbah sudah terolah dengan baik yakni dengan kandungan nutrien yang sedikit. Melalui pengolahan ini, kandungan TSS pada effluen air hasil pengolahan untuk variabel C2-A2 adalah 0,04 mg/L, sehingga sudah memenuhi baku mutu air bersih

\section{KESIMPULAN/RINGKASAN}

Berdasarkan penelitian yang telah dilakukan, maka kesimpulan yang diperoleh adalah:

1. Karakteristik air limbah domestik pada Perumahan Bhaskara Jaya masih melampaui baku mutu air limbah menurut Peraturan Menteri Lingkungan Hidup No. 68 Tahun 2016 tentang Baku Mutu Air Limbah Domestik pada parameter TSS, BOD, COD, $\mathrm{N}$ dan $\mathrm{P}$.

2. Hasil yang diperoleh dari serangkaian pengolahan yang telah dilakukan adalah sebagai berikut:

a) Penurunan kandungan atau removal kandungan zat organik terbesar terdapat pada variabel C2-A2, yakni dengan variasi media $50 \%$ zeolith dan $50 \%$ arang aktif, serta dosis penambahan EM4 yakni 5\%. Rata-rata penyisihan kandungan zat organik mencapai 93,14\%.

b) Penurunan kandungan atau removal nilai TDS terbesar terdapat pada variabel C2-A2, yakni dengan variasi media $50 \%$ zeolith dan $50 \%$ arang aktif, serta dosis penambahan EM4 yakni 5\%. Rata-rata penyisihan nilai BOD mencapai 84,76\%. c) Removal nilai P terbesar terjadi pada variabel C2-A2, yakni dengan variasi media $50 \%$ zeolith dan $50 \%$ arang aktif, serta dosis penambahan EM4 yakni 5\% dari debit air baku. Rata-rata penyisihan nilai $\mathrm{P}$ mencapai 99,67\%.

d) Removal terbesar untuk parameter $\mathrm{N}$ ada pada variabel C2-A2, yakni dengan variasi media $50 \%$ zeolith dan $50 \%$ arang aktif, serta dosis penambahan EM4 yakni 5\%. Rata-rata penyisihan nilai $\mathrm{N}$ mencapai 99,81\%.

e).Removal terbesar untuk parameter TSS ada pada variabel C2-A2, yakni dengan variasi media $50 \%$ zeolith dan $50 \%$ arang aktif, serta dosis penambahan EM4 yakni 5\%. Nilai penyisihan TSS mencapai 99,97\%..

\section{DAFTAR PUSTAKA}

[1] J. Nadayil, D. Mohan, K. Dileep, M. Rose, and R. R. P. Parambi, “A Study on Effect of Aeration on Domestic Wastewater.," Int. J. Interdiscip. Res. Innov. ISSN 2348-1226, vol. 3, no. 2, pp. 10-15, 2015.

[2] N. G. A. M. Dwi, A. Suastuti, N. Simpen, and D. N. Ayumi, "Efektivitas Penurunan Kadar Surfaktan Linier Alkil Sulfonat (LAS) dan COD dari Limbah Cair Domestik dengan Metode Lumpur Aktif,” J. Kim., vol. 9, no. 1, pp. 86-92, 2015.

[3] I. Mubarokah, "Gabungan Metode Aerasi dan Adsorpsi dalam Menurunkan Fenol dan COD pada Limbah Cair UKM Batik,” Universitas Negeri Semarang, 2010.

[4] E. M. Rashed and M. Massoud, "The effect of effective microorganisms (EM) on EBPR in modified contact stabilization system,” HBRC J., vol. 11, no. 3, pp. 384-392, Dec. 2015.

[5] L. Edahwati and D. Suprihatin, "Kombinasi Proses Aerasi, Adsorpsi, dan Filtrasi pada Pengolahan Air Limbah Industri Perikanan,” J. Ilm. Tek. Lingkung., vol. 1, no. 2, pp. 79-83, 2009.

[6] U. Munawaroh, "Penyisihan Parameter Pencemar Lingkungan pada Limbah Cair Industri Tahu menggunakan Efektif Mikroorganisme 4 (EM4) serta Pemanfaatannya,” REKA Lingkung., vol. 1, no. 2, 2013.

[7] S. Purwoto and W. Nugroho, "Removal Klorida, TDS, Dan Besi Pada Air Payau Melalui Penukar Ion Dan Filtrasi Campuran Zeolit Aktif Dengan Karbon Aktif,” WAKTU, vol. 11, no. 1, pp. 47-59, Jan. 2013. 